\title{
Effect of Deferent Type of Training on C-reactive protein Level in Healthy Middle Age Men
}

\author{
Mohammad Al Hindawi, PhD \\ Majed Mjallie, PhD \\ University of Jordan, Amman-Jordan \\ College of Physical Education- Department of Exercise Physiology
}

doi: 10.19044/esj.2016.v12n20p136 URL:http://dx.doi.org/10.19044/esj.2016.v12n20p136

\begin{abstract}
Objective: The goal of our study was to investigate the effect of different type of exercise training on C-reactive protein level in middle age men.

Methods: A total of 20 male subjects' mean age $45 \pm 5$ years were investigated at the University of Jordan Hospital to evaluate CRP level after training. Subjects were divided randomly into two groups they participated in supervise exercise training resistance and endurance exercise for 11 weeks. CRP level was measured pre-post training.
\end{abstract}

Results: Mean C-reactive protein level measured before training program was $1.82 \mathrm{mg} / \mathrm{L}$. And $1.81 \mathrm{mg} / \mathrm{L}$ for endurance and resistance groups respectively. Measurement of the CRP after the completion of the exercise program was $1.654 \mathrm{mg} / \mathrm{L}$ and $1.764 \mathrm{mg} / \mathrm{L}$ for both groups the endurance and the resistance respectively. TC was significantly reduced from $199.1 \mathrm{ml} / \mathrm{dl}$ to $176.1 \mathrm{ml} / \mathrm{dl}$, for the endurance group and from $193.50 \mathrm{ml} / \mathrm{dl}$ to $181.60 \mathrm{ml} / \mathrm{dl}$, for the resistance group. TG reduced significantly from $172.2 \mathrm{ml} / \mathrm{dl}$ to 161.50 $\mathrm{ml} / \mathrm{dl}$ for the endurance group, and from $163.50 \mathrm{ml} / \mathrm{dl}$ to $159.20 \mathrm{ml} / \mathrm{dl}$ for the resistance group. HR at rest reduced from 79.63 b.pm to 74.47 b.pm for the endurance group, and from 77.50 b.pm to 74.6 b.pm for the resistance group. Fat \% reduced significantly from 25.25 to 23.22 for the endurance group and from 23.03 to 21.60 for the resistance group. BMI reduced from 28.82 to 27.41 for the endurance group and from 27.63 to 27.40 for the resistance group.VO2max increased significantly from 37.13 to $43.30 \mathrm{ml} . \mathrm{kg} . \mathrm{min}$ for the endurance group, and from 37.67 to 39.3 for the resistance group. HDL also increased from $46.12 \mathrm{mi} / \mathrm{dl}$ to $48.25 \mathrm{mi} / \mathrm{dl}$ for the endurance group, and increased from $42.70 \mathrm{mi} / \mathrm{dl}$ to $44.30 \mathrm{mi} / \mathrm{dl}$ for the resistance group

Training gropes had lower CRP, weight, BMI, and body fat after the completion of the exercise program. 
Conclusions: Plasma C-reactive protein levels are reduced in response to both strength and endurance exercise training in sedentary healthy men (there was no different in the type of exercise in reducing CRP level.

Keywords: C-reactive protein, inflammation markers, resistance exercises training, cardiovascular disease

\section{Introduction}

Cardiovascular disease (CVD) continues to be one of the leading causes of morbidity and mortality in the world according to the British Heart Foundation (2003), and both the Center for Disease and Prevention and by the American Heart Association. (2004).

Jordan is no exception, according to the latest report issued by the Ministry of health in Jordan 2004, cardiovascular disease is the leading cause of death in Jordan (37.1\%)

As evidence continues to accumulate that inflammation plays a role in the pathogenesis of atherosclerosis (Lippy, 2002). Markers of inflammation such as C-reactive protein (CRP) are being used extensively in epidemiological research Danesh, (2004). Recent research has shown it to be a more powerful predictor of cardiovascular risk than classical markers such as low density lipoprotein-cholesterol Ridker, (2003). CRP is a critical component of the immune system, a complex set of proteins that our bodies make when faced with a major infection or trauma. CRP was discovered nearly 70 years ago by scientists exploring the human inflammatory response. The role CRP plays in heart disease has only recently been uncovered. However, over a dozen major studies demonstrate that baseline levels of CRP in apparently healthy men and women are highly predictive of future risk of heart attack, stroke, sudden cardiac death, and the development of peripheral arterial disease Torzewski (2000), Pearson (2003), and Danesh (2004), Balucci(2010). Normal values for CRP are not well defined, nonetheless from the data available, values less than $1.0 \mathrm{mg} / \mathrm{L}$ are considered low risk, $1.0-3.0 \mathrm{mg} / \mathrm{L}$ are considered medium risk , and greater than $3.0 \mathrm{mg} / \mathrm{L}$ high risk. Pearson, (2003).

Recent investigations have observed the association between physical activities and reduce risk of (CVD).Raul (2010), King (2003 and Hamer, (2007). Regular physical activity is associated with decrease in all cause of mortality especially CVD Paffengren, (1997) Wannamethee, (1998) and Johansson (1999). Many recent evidences has provided substantial support for exercise intervention-induced reduction in circulating markers of inflammation Targher, (1996), Lowe (2002), and Wannamethee (2002). These studies suggested that regular physical exercise might lower CRP levels in the body by reducing total fat, and can possibly be used as a means 
of reducing elevated CRP level, Geffen, (2001), You (2004) and Church (2010).

Okita et al (2004) found that a two-month aerobic exercise program significantly reduced CRP from 0, 63 to $0.41 \mathrm{mg} / \mathrm{l}$ in 199 women. However, a number of studies have shown that exercise programs do not influence these markers of inflammation Marcell, (2005) Nassis, (2005), and Hammet (2004). A recent published meta-analysis concluded that aerobic training did not significantly alter CRP level Kelley, (2006).

Despite these findings, emerging data supports the ability of physical training to reduce circulating levels of CRP in diseased populations Castaneda (2004), White (2006), Brooks, (2007) Arikawa (2011), and However, there is no consensus on the influence of different mode of training involving resistance and endurance training on CRP level in apparently healthy meddle age men in Jordan or in the Middle East.

Therefore, the current study was planned to determine the effects of different mode of training strength and endurance exercise training on Creactive protein (CRP) concentration in apparently healthy meddle age men in Jordan.

We hypothesized that different type of training induced different Creactive protein reduction among healthy individuals who have low to moderate baseline C-reactive protein level and who therefore are at increased risk of cardiovascular disease.

\section{Methods}

All participants were recruited through advertisements and flyers posted and distributed at the local hospital and fitness centers in Amman. This study was approved by the scientific committee for higher education at physical education college .Criteria for participation in the studies included the following CRP level $\geq 1.7 \mathrm{mg} / \mathrm{L}$, nonsmokers, no known heart disease, no lipid modifying medications and aerobically active $<1$ hour a week, not having chronic disease or taking medication that prevented their participation in structured exercise training, and any other condition that may interfere with interpretation of the study results. Individuals who participated in the study were volunteers and were not given any kind of remuneration. The participants were informed about testing procedures, possible risks and discomfort that might ensue and gave their written informed consent to participate in accordance with the Helsinki Declaration WMADH, (2000).

Of 35 persons who responded to a public request for volunteers, 20 mean age $45 \pm 5 y$ rs met the criteria who had serum CRP level that placed them on the risk of future heart attack (risk ratio $\geq 1.7 \mathrm{mg} / \mathrm{L}$ ) Ridker, (1997), Danesh, (1998), and Metine, ( 2006). The subjects, table (1) were randomly assigned into to two groups group 1 (strength exercise group) assigned to 
supervised strength exercise program. Group 2 assigned to endurance training group. The two groups were similar in age, BMI, height and weight.

Table 1 Mean Physical Characteristics of study subjects

\begin{tabular}{ccc} 
Subjects Characteristics & Group 1(endurance) & Group 2 (resistance) \\
\hline Age (yrs) & 45.7 & 45.5 \\
Weight (kg) & 90.8 & 85.1 \\
Height (m) & 1.775 & 1.755 \\
BMI (kg/m2) & 28.82 & 27.63 \\
BF (\%) & 25.31 & 23.4 \\
Resting heart rate(bpm) & 79.62 & 78.98 \\
VO2 max(ml.min. kg) & 37.75 & 35.60 \\
Systolic (BP)(mmhg) & 135.3 & 136.0 \\
Diastolic (BP) (mmhg) & 86.62 & 84.6 \\
\hline
\end{tabular}

\section{Measurements}

During one day preceding tests, the participants refrained from training and maintained their normal diet. Laboratory tests were carried out on the same day in similar conditions for both groups. Room temperature was $23^{\circ} \mathrm{C}$ and relative humidity was 50\%. Pre and post training venous blood sampling were conducted in the morning following an overnight fast at the University of Jordan hospital Lab. The same medical staff collecting blood samples for both groups and in pre and post training. The primary outcome measure will be plasma CRP concentration secondary outcome will be Total cholesterol triglycerides; high-density lipoprotein (HDL), Low density lipoprotein (LDL), BMI and fat\%. Blood profiles were compared at baseline and after the training program have been completed for the mentioned variables. All variables were assessed at baseline and after the exercise training program by using the same study protocols and methods.

\section{Exercise testing and procedures}

All participants underwent standard graded exercise treadmill test using modified Bruce protocol. 12-lead electrocardiogram were recorded, Blood pressure (BP) using sphygmomanometer (ms-900) and heart rate (HR) was monitored. Subjects were exercised until reaching their $90 \%$ of there maximal heart rate. Subjects who had abnormal exercise stress test were excluded from the study. The treadmill test was terminated according to the guidelines recommended by the American College of Sports Medicine Balady, (2000).

Body weight and height were measured with standard techniques and body mass index (BMI) was calculated as an index of total body mass. Skinfold thickness at sites of suprailiac, subscapular, triceps, and abdomen were measured on the right side of the body using a Holtain caliper (Holtain Ltd, Crymych, UK) and for each participant the average of two 
measurements was recorded. Percentage of body fat (\%BF) was estimated using Robergs, (2003) equation.

Subjects, table (1) were randomly assigned into to two groups group 1 (strength exercise group) assigned to supervised strength exercise program. Group 2 assigned to endurance training group. The two groups were similar in age, BMI, height and weight.

Training program for the strength group was performed at fitness one facilities, the training program were designed to mimic exercise programs typically performed by sedentary individuals using commercial equipment (Nordic Track equipment; Nordic track, Glencoe, MN) designed for home use.

Exercising individuals for group 1 will participated in supervised resistance program about 60 minute exercise sessions 3 time a week for period of 11 week using commercially available resistance training exercise equipment(Nordic Flex Gold, Glencoe, MN). All participants were instructed on the proper technique for each exercise by a trained instructor and were familiarized with the equipment before training. The resistance training program consisted of three sets 10 lifts/set and a three parts. Subjects preformed a brief warm-up period lasts for 10-15 minutes consisting of static stretching before and after each training session., the second parts is a supervised exercise session which lasted about 45 minutes and including resisting exercise for the major muscles including, military press, bench press, pull back, biceps curl, triceps push-down, leg curl and extension and sit up. The last part consists of 5 minuets cool-down exercise and stretching exercises. Participants trained with a partner and all training sessions were carefully supervised by the investigator and the gym staff. Each subject was encouraged to perform each set and repetition with utmost effort. Increase in strength was documented by comparing the average weight lifted during 10 repetitions. The target exercise intensity will be progress from $40-70 \%$ of $1 \mathrm{MR}$

Group two the endurance subjects will participated in supervised program about 60 minute exercise sessions 3 time a week for period of 11 week, these sessions consisted of three parts a warm-up period lasts for 1015 minutes, the second parts is a supervised exercise session which lasted about 50 minutes and includes walking on the treadmill , and aerobic exercise. The last part consists of 10 minuets cool-down and stretching exercises. The target exercise intensity will be progress from $50-70 \%$ of max HR. The subjects were instructed not to change their lifestyle during the exercise intervention. Maximal oxygen uptake increased by 18\% (from 37.75 to $43.30 \mathrm{ml} / \mathrm{kg} / \mathrm{min}$ ) during 11 weeks of exercise indicating the effectiveness of the training program. 


\section{Statistical analyses}

Statistical analysis was carried out using SPSS package (copy 10). The comparisons between pre-exercise and pos-exercise values were analyzed by nonparametric Wilcoxon's test for statistically significant. Numerical values are expressed as mean \pm SD. (Mann Whitney U) test was used to compare the two groups in pre and post measurements. A value of ( $\mathrm{p}$ $<0.05$ ) was considered statistically significant.

\section{Results}

Resistance and endurance groups were not significantly different with regarded to baseline values of CRP, LDL,HDL, TG,TC,VO2 max, Fat\%, HR at rest, weight and B/P Table 2 show means and Sd for the investigated variables.

Mean C-reactive protein level measured before training program was $1.82 \mathrm{mg} / \mathrm{L}$. And $1.81 \mathrm{mg} / \mathrm{L}$ for endurance and resistance groups respectively. Measurement after the completion of the exercise program was $1.65 \mathrm{mg} / \mathrm{L}$ and $1.764 \mathrm{mg} / \mathrm{L}$ for both groups the endurance and the resistance respectively. There was a significant reduction in the concentration of CRP $\mathrm{p} \geq 0.05$ in favor of the post training program for both groups.

Mean TC also was significantly reduced from $199.1 \mathrm{ml} / \mathrm{dl}$ to 176.1 $\mathrm{ml} / \mathrm{dl}$, for the endurance group and from $193.50 \mathrm{ml} / \mathrm{dl}$ to $181.60 \mathrm{ml} / \mathrm{dl}$, for the resistance group.

TG reduced significantly from $172.2 \mathrm{ml} / \mathrm{dl}$ before the training to $161.50 \mathrm{ml} / \mathrm{dl}$ after the completion of the training program for the endurance group, and from $163.50 \mathrm{ml} / \mathrm{dl}$ to $159.20 \mathrm{ml} / \mathrm{dl}$ for the resistance group.

$\mathrm{HR}$ at rest also reduced from 79.62 b.pm before training to 74.37 b.pm after training for the endurance group, and from 77.50 b.pm before training to 74.6 b.pm for the resistance group. Fat \% reduced significantly from 25.25 to 23.22 for the endurance group and from 23.03 to 21.60 for the resistance group. BMI reduced from 28.82 to 27.41 for the endurance group and from 27.63 to 27.40 for the resistance group.

VO2max increased significantly from 37.75 to $43.30 \mathrm{ml} . \mathrm{kg} . \mathrm{min}$ for the endurance group, and from $37.67 \mathrm{ml} . \mathrm{kg} . \mathrm{min}$ to $39.3 \mathrm{ml} . \mathrm{kg} . \mathrm{min}$ for the resistance group. HDL increased from $46.12 \mathrm{mi} / \mathrm{dl}$ to $48.25 \mathrm{mi} / \mathrm{dl}$ for the endurance group, and from $42.70 \mathrm{mi} / \mathrm{dl}$ to $44.30 \mathrm{mi} / \mathrm{dl}$. for the resistance group

Training grope had lower weight, BMI, and body fat after the completion of the exercise program. Table 2. 
Table 2 Means and St.d for the measured variables for both groups Endurance and Resistance training groups

\begin{tabular}{|c|c|c|c|c|}
\hline \multirow[t]{2}{*}{ Variables } & \multicolumn{2}{|c|}{$\begin{array}{l}\text { Mean and Sd for the endurance } \\
\text { group }\end{array}$} & \multicolumn{2}{|c|}{$\begin{array}{l}\text { Mean and Sd for the resistance } \\
\text { group }\end{array}$} \\
\hline & Pre & pos & Pre & post \\
\hline $\begin{array}{l}\mathrm{CRP} \\
\mathrm{ml} / \mathrm{dl}\end{array}$ & \multicolumn{2}{|c|}{$\begin{array}{c}1.821( \pm 0.063) \\
( \pm 20.46)\end{array}$} & \multicolumn{2}{|c|}{$\begin{array}{c}1.81 \underset{( \pm 0.015)}{( \pm 0.042)} \\
\qquad .7646\end{array}$} \\
\hline $\begin{array}{l}\text { Tc } \\
\mathrm{Ml} / \mathrm{dl}\end{array}$ & $199.1( \pm 32.64)$ & $176.1( \pm 24.64)$ & $\begin{array}{r}193.50( \pm 8.79 \\
( \pm 9.9\end{array}$ & 181.60 \\
\hline $\begin{array}{c}\mathrm{BMI} \\
(\mathrm{Kg} / \mathrm{m} 2)\end{array}$ & $28.82( \pm 4.56)$ & $27.41( \pm 3.49)$ & $27.63( \pm 2.75)$ & $27.40 \pm 1.77)$ \\
\hline $\begin{array}{l}\mathrm{LDL} \\
\mathrm{Ml} / \mathrm{dl}\end{array}$ & $117.8( \pm 33.58)$ & $98.7( \pm 26.4)$ & \multicolumn{2}{|c|}{$\begin{array}{c}118.10( \pm 11.38) \\
104.70( \pm 9.38)\end{array}$} \\
\hline $\begin{array}{l}\text { VO2Max } \\
\text { (Ml.min.kg) }\end{array}$ & $37.75( \pm 4.02)$ & $43.30( \pm 5.23)$ & \multicolumn{2}{|c|}{$\begin{array}{r}37.67( \pm 3.48) \\
( \pm 3.97)\end{array}$} \\
\hline $\begin{array}{l}\mathrm{HDL} \\
\mathrm{Ml} / \mathrm{dl}\end{array}$ & $46.12( \pm 10.45)$ & $48.25( \pm 9.68)$ & $\begin{array}{r}42.70( \pm 9.17) \\
( \pm 6.1\end{array}$ & 44.30 \\
\hline $\begin{array}{l}\text { TG } \\
\mathrm{Ml} / \mathrm{dl}\end{array}$ & \multicolumn{2}{|c|}{$\begin{array}{l}172.2( \pm 73.02) \\
161.50(+56.63)\end{array}$} & \multicolumn{2}{|c|}{$163.50( \pm 16.07)$} \\
\hline $\begin{array}{r}\text { HRrest } \\
(\mathrm{bpm})\end{array}$ & $79.62( \pm 4.44)$ & $74.37( \pm 3.50)$ & $77.50( \pm 2.59)$ & $74.6( \pm 3.13)$ \\
\hline FAT\% & $25.25( \pm 4.27)$ & $23.22( \pm 3.49)$ & $23.03( \pm 4.09)$ & $21.6( \pm 1.91)$ \\
\hline $\begin{array}{l}\text { Weight } \\
\text { (Kg) }\end{array}$ & $90.8( \pm 15.42)$ & $86.37( \pm 11.49)$ & $85.10( \pm 4.40)$ & $84.4( \pm 3.08)$ \\
\hline
\end{tabular}

Data are presented as the mean and S.D. BMI = body mass index, TC=total cholesterol, HDL=high density lipoprotein, LDL= low density lipoprotein, $\mathrm{CRP}=\mathrm{C}$-reactive protein.

\section{Discussion}

In this study, we investigated the effects of different type of exercise training (strength and endurance) training on CRP level among a representative sample of apparently healthy middle aged men in Jordan. Specifically we tested the hypothesis that different type of training would induce different reductions in CRP level and therefore reducing CHD of apparently healthy middle aged men in Jordan.

The results of this study show that CRP concentration is markedly lower in the resting stat in resistance and endurance subjects

Overall, these results suggest that resistance and endurance exercise training may be associated with lower levels of systemic inflammation 
among healthy men who are 45 years or older. A training induced reduction in CRP is supported by a few similar investigations Andrew (2012), Michal (2011), Mattusch, (2005), and Okita, (2004).

Previous studies had similar results they reported that high activity level were associated with lower inflammation markers CRP Tisi, (1997), Smith, (1999), Mattuch, (2000), King, (2003), Esposit (2003), Tomszwek, (2003), Aronson (2004), and You, (2004).

On the other hand, many interventions have shown less of a decrease, when active individuals were compared with inactive individuals; higher levels of physical activity have been associated with lower concentration of CRP Aronson, (2004), Pischon, (2003) and Reuben, (2003). There are established relationships among CRP, percent body fat, fat mass and BMI Khaodhiar, (2004). Although our results support the positive relationship between CRP and percent of body fat, it has been hypothesized body fat reduction my results in decrements in CRP concentration Tchernof, (2002), and Dvorakova (2006).

Obesity is a factor that strongly related to high level inflammation, and is a strong predictor of CRP Yudkin, (1999), Hak (1999), Visser (1999), Lemieux (2001) and Tracy (2001). And other inflammatory markers Bao, (1993), Cacciari, (1998), Fergusson, (1998) and Shea (1999). And it has been suggested that physical activity may reduce inflammation by reducing body weight and obesity level Folson (1999), Geffken, (2001), Abramson (2002), Esposit, (2003) and You, (2004). However, in the present study, we observed that physical activity was associated with lower weight. And probably the redaction in weight was responsible in the lower CRP level; however, there was no significant association between the reduction in body weight, BMI and CRP level in our study. That's probably is due to smaller sample size or the short duration of the study, longer intervention periods have been found to be more effective in reducing BMI and body fat percentage Wolmore, (1999). Our findings are consistent with those reported by Okita, (2004). Who found that there is no association between weight loss and reduction on CRP level?

\section{Training response}

Many cross-sectional studies demonstrate an inverse relationship between regular physical activity and serum concentration of inflammatory marks, Dufaux (1984) reported the effects of exercise training on CRP and were significantly lower in swimmer and rowers. Tisi, (1997), Mattuch ,(2000) , Taaffe, (2000) , Wannamethee , (2002) , King, (2003), Pitsavos, (2003), and Albot , (2004) . They examine the effects of exercise training on CRP level they demonstrated that CRP level were significantly reduced after endurance supervised training compared with controls. These 
intervention studies support the concept that exercise training reduces CRP level by altering the inflammatory process in consistent with our finding,

Other studies were in disagree with our finding two recent studies failed to confirm an independent inverse relationship between chronic physical activity and inflammation markers Rawason, (2003) and Verdaet, ( 2004). One explanation for the absence of an exercise effect in these studies may be the high proportion of sedentary subjects.

Other reported that Cardio respiratory fitness was inversely related to CRP level increase cardio respiratory fitness was associated with decreased CRP level Church, (2002), Lamonte, (2002), and Isasi, (2003).

\section{Exercise intensity}

The effects of regular physical activity on CRP level concentration values in moderate intensity were significantly lower than strenuous exercise , King, (2003) reported that moderate endurance activity (joggers and aerobic dancers) were significantly had lower CRP level similar to our finding.

Several studies were in disagreement with our finding they demonstrated marked increase in CRP level immediately and $24 \mathrm{~h}$ after strenuous exercise Weight, (1994) and Sigel (2002). During short exercise CRP increased temporarily and is directly related to exercise intensity and duration. Ostroski, (1999), and Pederson, (2000).

They suggested that exercise-induced muscle injury has been thought to bee the primary stimulus for the increased CRP responded values returned to baseline two to six days after exercise. That was not the case in our study. In our study there was significant decrease in the CRP level after moderate intensity training,

Long term exercise or physical training appears to reduce the acute response to strenuous activity Febbrraio, (2002). Post run CRP were reduced by $40 \%$ after training. Longitudinal exercise training studies demonstrate a long-term anti-inflammatory effect, Tisi, (1997) this anti-inflammatory response may contribute to the beneficial effects of habitual physical activity. The possible inflammation suppressing effect of exercise training may partly explain the effectiveness of regular physical activity in the prevention and treatment of cardiovascular diseases Lakka, (1993) , Paffengren, ( 1997, Wannamethee ,(1998) , Sacco,( 1998), Hambrech, ( 2000), Lankkanen, ( 2001), Laaksonen,( 2001a and 2002b).

Aerobic exercise effect on CRP concentration demonstrate an inverse association between physical activity and CRP one of these studies. Wannamethee (2002) examine change in physical activity over the course of 20 years and showed that inactivity men who become active had CRP values approaching those of men who remained at least lightly active conversely, those who become inactive had CRP level similar to these who remained 
inactive, suggesting that physical activity has to be continuous to maintain its effects on CRP.

The role and the mechanisms in reducing CRP level with regular physical activity is not well defined exercise is related to several confounders that are associated with lower CRP level including age, smoking, hypertension, BMI, total cholesterol and triglycerides. Those factors are directly related to CRP concentrations Fored,(2003) Individuals who are obese have increased the production of inflammatory markers including CRP Visser (1999), Yadkin, ( 1999) , Mclanghlin ,(2002) and Esposit ,(2003). . Previous studies suggest that regular physical activity could suppress inflammation by reducing body adiposity level, (Geffken 2001, Esposit, (2003) and You, (2004). Individuals with high BMI also associated with increased level of CRP King, (2003), Tomszesk, (2003), and Aronson, (2004). By improving endothelial function preserving nitric oxide availability Romano, (1997), and Taddei (2000). The antioxidant effect of exercise reduces susceptibility of low density lipoprotein to oxidation Shern, (1998).Which in turn helps further prevent endothelial injury and inflammation Berliner, (1995) and Witzum (1997). In summary, its likely that exercise training reduces CRP both directly by reducing cytokine production in fat , muscle and mononuclear cells and indirectly by increasing insulin sensitivity improving endothelial function and reducing body weight.

\section{Conclusion}

Plasma C-reactive protein level are reduced in response to both strength and endurance exercise training in sedentary healthy men in Jordan .This finding may partly explain the effectiveness of regular physical activity in the prevention and treatment of cardiovascular diseases. A longer intervention could have resulted in a larger C-reactive protein reduction. A weakness of the study is the lack of female subjects in the study.

\section{References:}

Abramson, JL. Vaccarino, V. (2002). V. Relationship between physical activity and inflammation among apparently healthy middle-aged and older U.S. adults Arch Intern Med, 162, 1286-1286.

Albert M A, Glynn RJ, Ridker PM. (2004). Effect of physical activity on serum C-reactive protein Am J Cardiol, 13, 561-568.

American Heart Association and Center for disease and prevention.(2004)

- Andrew Michigan Timothy V Viraj A. (2012) Review of the relationship between $\mathrm{C}$ - reactive protein and Exercise. Med Sci Sports Exerc. 42(4): 701-707. doi: 10.1249/MSS.0b013e3181c03a2b15 
Arikawa AY, Thomas W, Schmitz KH. (2011) Sixteen weeks of exercise reduces C-reactive protein Level in young women. Med Sci Sports Exerc 43(6):1002-1009. Doi: 10.1249/Mss.0b013e3182059eda

Aronson D, Sheik-Ahmad M, Avizohar O, et al. (2004). C-reactive protein is inversely related to physical fitness in middle-aged subjects Atherosclerosis, 176,173-170.

Balady JG, Berra AK, Golding AL, Gordon FN, Mahler AD, Myers NJ, et al. (2000). ACSM”s guides for exercise testing and prescription. In: William Lippincott, Willkins Lippincott, editors . $6^{\text {th }}$ ed.

Balducci S, Zanuso S, Nicolucci A, Fernando F. (2010). Anti-inflammatory effect of exercise training in subjects with type 2 diabetes and the metabolic syndrome is dependent on exercise modalities and independent of weight loss. Nutrition, Metabolism and cardiovascular Diseases, 20, 608-617. Doi:10.1016/j.numecd.2009.04.015

Bao W, Srinivasan SR, Salman H, et al. (1993). Plasma fibrinogen and its correlates in children from a biracial community: the Bogalusa Heart Study. Pediatr Res, 33, 323-326.

Berliner JA, Navan M, Fogelman AM, et al. (1995). A atherosclerosis: basic mechanisms. Oxidation, inflammation, and genetics. Circulation. 91, 248896.

British Heart Foundation. Coronary Heart disease Statistics. Available at: www.dphpcox.ac.uk/bhfhprg/stats 2003.

Brooks, N., J. E. Layne, P. L. Gordon, R. Roubenoff, M. E. Nelson, and C. Castaneda-Sceppa. (2007). Strength training improves muscle quality and insulin sensitivity in Hispanic older with type 2 diabetes. Int J. Med. Sci. 4, 19-27.

Cacciari E, balsamo A, Palareti G, et al. (1988). Haemorheologic and fibrinolytic evaluation in obese children and adolescents. Eur J Pediatr, 147, 381-384.

Castaneda, C., P. L. Gordon, R.C. Parker, K. L. Uhlin, R. Roubenoff, and A.S. Levey. (2004). Resistance training to reduce the malnutritioninflammation complex syndrome of chronic kidney disease. Am. J. Kidney Dis. 43, 607-616.

Church TS, Barlow CE, Earnest CP, Kampert JB, Priest EL, Blair SN. A. (2002). Associations between cardiorespiratory fitness and C-reactive protein in men. Arterioscler Thromb Vasc Biol, 22, 1869-1876.

Church T, Conrad P, Angela M, Elisa P. (2010) Exercise without weight loss dose not reduces $\mathrm{C}$ - reactive protein: The Inflame Study. Med Sci Sports Exerc 42,(4) 708-716. Doi: 10.1249/Mss.0b013e3181c03a43 
Damon L, Swift. Neil M, Johannsen Conrad P, Steven N.(2012) The effects of exercise training modality on C-reactive protein in type-2 diabetes. Med Sci Sports Exerc. 44(6): 1028-1034. doi: 10.1249/MSS.0b013e31824526cc Danesh J, Wheeler JG, Hirschfield GM et al. (2004). C-reactive protein and other circulating markers of inflammation in the predication of coronary heart disease. N Engl J Med, 350, 1387-1397.

Danesh J, Collins R, Appleby P, et al. (1998). Association of fibrino-gen, Creactive protein, albumin, or leukocyte count with coronary heart disease: meta-analyses of prospective studies. JAMA. 279, 1477-82.

Dufaux B, Order U, Geyer H, Hollmann W. (1984). C-reactive protein serum concentration in well-trained athletes Int J Sports Med, 5, 102-106.

Dvorakova-Lorenzova, A., P. Suchanek, P.J.Havel, et al. (2006). The decrease in C-reactive protein concentration after diet and physical activity induced weight reduction is associated with changes in plasma lipids, but not interleukin-6 or adiponectin . Metabolism 55, 305-365.

Esposit K, Pontillo A, Di palo C; et al. (2003). Effect of weight loss and lifestyle changes on vascc -inflammatory marker in obese women: a randomized trail.JAMA, 289, 1799-1804

Febbrraio MA, Pederson BK. (2002). Muscle-derived interleukin6mechanisms for activation and possible biological roles. FASEB J, 16, 1335-1347.

Fergusson M, Gutin B, Owens S, et al. (1998). Fat distribution and hemostatic measures in obese children. AM J Clin Nutr, 67, 1136-1140.

Folsom A, Conlan M, Davis C, et al. (1992). Relations between homeostasis variables and cardiovascular risk factors in middle-aged adults. Atherosclerosis Risk in Communities (ARIC) Study Investigators. Ann Epidemiol, 2, 481-94.

Fored ES. (2002). Does exercise reduce inflammation? Physical activity and C-reactive protein among U.S. adults Epidemiology, 13 (5), 561-568.

Freeman DJ, Norrie j, Caslake MJ, et al. (2002). C-reactive-protein is an independent predictor of risk for the development of diabetes in the West of Scotland Coronary Prevention Study. Diabetes, 51, 1596-1600.

Geffken DF, Cushman M, Burke GL, Polak JF, Sakkinen PA, Tracy RP. (2001). Association between physical activity and markers of inflammation in a healthy elderly population. Am J Epidemiol, 153, 242-250.

Hak AE, Stehouwer CD, Bots ML, Polderman KH, Schalkwijk CG, Westendorp IC, Hofman A, Witteman JC. (1999). Association of C-reactive protein with measures of obesity, insulin resistance and subclinical atherosclerosis in healthy, middle-aged women. Arterioscler Thromb Vasc Biol, 19, 19886-1991. 
Hambrecht R, Wolf A, Gielen S, Linke A, Hofer J, Erbs S, Schoene N, Schuler G. (2003). Effect of exercise on coronary endothelial function in patients with coronary artery disease. N Engl J Med, 342, 454-460.

Hammett, C. J., H. C. Oxenham, J. C. Baldi, et al. (2004). Effect of six months' exercise training on C-reactive protein level in healthy elderly subjects. J. Am Coll. Cardio, 44, 2411-2413.

Isasi CR, Deckelbaum RJ, Tracy RP, Starc TJ, Bergulund L, Shea S. (2003). Physical fitness and C-reactive protein level in children and young adultsthe Columbia University BioMarkers Study. Pediatrics, 111, 332-338.

Johansson, S.E, and Sundquist, J. (1999). Change in lifestyle factors and their influence on health status and all-cause mortality. International Journal of Epidemiology. 28,1073-1080.

Kelley, G.A., and K.S. Kelley. (2006). Effects of aerobic exercise on Creactive protein, body composition, and maximum oxygen consumption in adults: a meta-analysis of randomized controlled trials. Metabolism, 55, 1500-1507.

Khoadhiar, L., P. R. Ling, G. L. Blackburn, and B. R. Bistrian. (2004). Serum levels of interleukin-6 and C-reactive protein correlate with body mass index across the broad range of obesity. JPEN J> Parenter. Enteral Nutr, 28, 410415.

King DE, Carek P, Mainous III AG, Pearson WS. (2003). Inflammatory markers and exercise differences related to exercise type. Med Sci Sports Exerc, 35, 575-581.

Laaksonen DE, Lakka HM, Salonen JT, Niskanen LK, Rauramaa R, Lakka TA. (2002). Low level of leisure-time physical activity and cardio respiratory fitness predict development of the metabolic syndrome. Diabetes Care, 25, 1612-1618.

Laaksonen DE, Lindstrom J, Laaka TA, Eriksson JG, Niskanen LK, Wikstrom K, et al . (2005). Physical activity in the prevention of type 2 diabetes: The Finnish Diabetes Prevention Study. Diabetes, 54, 158-165.

Lakka TA, Salonen JT. (1993). Moderate to high intensity conditioning leisure time physical activity and high cardiorespiratory fitness are associated with reduced plasma fibrinogen in eastern Finnish men. J Clin Epidemiol , 46, 1119-27

Lamonte MJ, Durstine IL, Yanowitz FG, et al. (2002). Cardiorespiratory fitness and C-reactive protein among a tri-ethnic sample of women Circulation. 106, 403-406.

Laukkanen J A, Lakka TA, Rauramaa R, Kuhanen R, Venalainen JM, Salonen R, Salonen JT. (2001). Cardiovascular fitness as a predictor of mortality in men. Arch Intern Med, 161, 825-831.

Liesen H, Dufaux B, Hollman W. (1977). Modification of serum glycoproteins the days following a prolonged physical exercise and the 
influence of physical training Eur J Apple Physiol Occup Physiol, 37, 243254.

Lipp. P,Ridker, P., Maseri, A. (2002). Inflammation and atherosclerosis. Circulation, 105, 1135-1143.

Lowe GD, Rumley A, Whincup PH, et al. (2002). Hemostatic and rheological variables and risk of cardiovascular disease. Semin Vasc Med, 2, 429-39

Marcell, T. J., K.A> McAuley, T. Traustadottir, and P.D. (2005). Reaven. Exercise training is not associated with improved levels of $\mathrm{C}$ - reactive protein or adiponectin. Metabolism, 54, 533-541.

Mattuch F, Dufaux B, Heine O, Mertens I, Rost R. (2000). Reduction of the plasma concentration of C-reactive protein following nine months of endurance training. Int J Sports Med, 21, 21-24.

Mclaughlin T, Abbasi F, Lamendola C, et al. (2002). Differentiation between obesity and insulin resistance in the association with C-reactive protein. Circulation, 106, 2908-2912 47.

Metin Ergun , Istemihan Tengiz, Ugur Turk, Seckin Senisik, Emin (2006). Alioglu Oguz Yksel Ertugrul Ercan , Cetin Islegen. Jour Spo Scie Medic, 5, 266-275.

Mortality data in Jordan, 2004 Ministry of health, Jordan.

Michal G, Nicolette C, David J, Stensel M (2011) The anti-inflammatory effects of exercise mechanisms and implications for the prevention and treatment of disease. Progress in Cardiovascular diseases. 53(6) 397-403.

Nassis, G. P., Papantakous, K Skenderi, et al. (2005). Aerobic exercise training improves insulin sensitivity without changes in body weight, body fat, adiponectin, and inflammatory markers in overweight and obese girls. Metabolism, 54, 1472-1479.

Okita K, Nishijma H, Murakami T; et al. (2004). Can exercise training with weight loss lower serum C-reactive protein level? Arterioscler Thromb Vasc Biol., 24, 1868-1873.

Ostrowski K, Rohde T, Zacho M, Asp S, Pedersen BK. (1998). Evidence that interleukin-6 is produced in human skeletal mucle during prolonged running J Physiol 508, 949-953.

Ostrowski K, Rohde T, Asp S, Schjerling P, Pederson BK. (1999). Pro-and anti-inflammatory cytokine balance in strenuous exercise in humans $\mathrm{J}$ Physiol, 515, 287-291.

Paffengren RS, Jr Lee, IM. (1997). Physical Activity and fitness for health and longevity. Res Q Sports, 67, s11-s28.

Pasceri V, Willerson JT, Yeh ET. (2000). Direct proinflammatory effect of C-reactive protein on human endothelial cells. Circulation, 102, 2165-2168.

Pearson T, A Mensah GA, Alexander R W, et al. (2003). Markers of inflammation and cardiovascular dieses: application to clinical and public 
health practice: a statement for healthcare professionals from the Centers for Disease Control and Prevention and the American Heart Association Circulation, 107, 499-511.

Pederson BK ,Homffman-Goetz L. (2000). Exercise and the immune system regulation, integration, and adaptation. Physiol Rev, 80, 1055-1081.

Pischon, T., S.E. Hankinson, G.S. Hotamisligil, N. Rifai, and E.B. Rimm. (2000). Leisure-time physical activity and reduced plasma levels of obesityrelated inflammatory markers. Obes. Res. 11, 1055-1064.

Pitsavos C, Chrysohoou C, Panagiotakos DB, et al. (2003). Association of leisure-time physical activity on inflammation markers (C-reactive protein, white cell blood count, serum amyloid A, and fibrinogen) in healthy subjects (from the ATTICA study) Am J Cardiol , 91, 368-370.

Rawason ES, Freedson PS, Osganninan SK, Mattews CE, Reed, G, Ockene IS. (2003). Body mass index, but not physical activity, is associated with Creactive protein .Med Sci Sports Exercise, 35, 1160-1166.

Reuben, DB. L. Judd-Hamilton, T.B.Harris, and T.E. Seeman. (2003). The association between physical activity and inflammatory markers in highfunctioning older persons: MaxArthur studies of successful aging. J. Am.Geriatr. Soc, 51, 1125-1130

Raul A, Martins. Ana P, Neves Manuel J, Verssimo.(2010) The effects of aerobic versus strength based training on high sensitivity C-reactive protein in older adults. European Journal of applied Physiology 110(1) 161-169. doi: 10.1097/HCR.0b013e3182122827

Ridker P, Cushman M, Stampfer M, et al. (1997). Inflammation, aspirin, and the risk of cardiovascular disease in apparently healthy men. N Engl Med, 336, 973-9.

Ridker PM, Buring JE, Cook NR, et al. (2003). C-reactive protein, the metabolic syndrome, and risk of incident cardiovascular events: an 8-years follow-up of 14719 initially healthy American women. Circulation, 107, 391-397.

Robergs, R. and Ketegian, S. (2003). Fundamentals of exercise physiology for fitness performance and health, (2th ed) New York: Mc Graw Hill company.

Romano M, Sironi M, Toniatti C, et al. (1997). Role of IL-6 and its soluble receptor in induction of chemokines and leukocyte recruitment. Immunity, 6, 315-325.

Roost R (1999). Atherosclerosis-an inflammatory disease N Engl J Med, 340, 115-126.

Sacco RL, Gan R, Boden-Albala B, Lin IF, Kargman DE, Hauser WA, Shea S, Paik MC. (1998). Leisur-time physical activity and ischemic strok risk: the North Manhattan Stroke Study. Stroke, 29, 380-387. 
Sesso HD, Buring JE, Rifai N, Blake GJ Gaziano JM, Ridker PM. C-reactive (2002)

Shea S, Isasi CR, Couch S, et al. (1999). Relations of plasma fibrinogen level in children to measures of obesity, the (G-455->A) mutation in the Bfibrinogen promoter gene, and family history of ischemic heart disease. The Columbia University BioMarkers Study. Am J Epidemiol, 150, 737-746?

Shern Brewer R, Santanam N, Wetzstein C, White-Welkley J, Parthasarathy S. (1998). Exercise and cardiovascular disease: a new perspective. Arterioscler Thromb Vasc Biol, 18, 1181-1187.

Sigel AJ, Stec JJ, Lipinska I, et al. (2002). Effect of marathon running on inflammatory and hemostatic markers Am J Cardiol, 88, 918-920.

Smith K,J Rhesa Dykes, E, John Guha Krishnaswamy. (1999). Long-tearm exercise and Atherogenic activity of blood mononuclear cell in person at risk of developing ischemic heart disease. JAMA, 281, 1722-1727.

Taaffe DR, Harris TB, Ferruccil, Rowe J, Seeman TE. (2000). Crosssectional and prospective relationships of interleukin-6 and C-reactive protein with physical performance in elderly persons MacArthur studies of successful aging.J Gerontol A Biol Sci Med Sci , 55, M709-M715.

Taddei S, Galetta F, Virdis A, Ghiadoni L, Salvetti G Franzoni F, Giusti C, Salvetti A . (2000). Physical activity prevents age-related impairment in nitric oxide availability in elderly athletes. Circulation, 101, 2896-2901.

Targher G, Seidell, J.C., Tonoli, M Muggeo, M De Sandre, G and Cig. (1996). The white blood cell count: its relationship to plasma insulin and other cardiovascular risk factors in healthy male individuals, Journal of Internal Medicine, 239, 435-451.

Tchernof, A., A. Nolan, C.K. Sites, P.A. Ades, and E.T. Poehlman. (2006). Weight loss reduces C-reactive protein levels in obese postmenopausal women. Circulation, 105, 564-569.

Tisi PV, Hulse M, Chulakadabba A, Gosling P, Shearman CP. (1997). Exercise training for intermittent claudication: dose it adversary affect biochemical markers of the exercise -induce inflammatory response? Eur $\mathrm{J}$ Vasc Endovasc Surg , 14, 344-350.

Tomszwesk M, Charchar FJ, Przybycin M, et al. (2003). Strikingly low circulating CRP concentrations in ultra marathon runners independent of markers of adiposity how low can you go? Arterioscler Thromb Vasc Biol , 23, 164-1644.

Torzewski M, Rist C, Mortensen RF, Zwaka TP, Bienek M, Waltenberger J, Koening W, Schmitz (2000). C-reactive- protein in the arterial intima: role of C-reactive protein receptor-dependent monocyte recruitment in atherogenesis. Arterioscler thromb Vasc Biol, 20, 2094-2099.

Verdaet, D Dendale, P. De Bacquer D. Delanghe, J. Block, P. and De Backer, G. (2004). Association between Leisure time physical activity and 
markers of chronic inflammation related to coronary heart disease. Atherosclerosis, 176, 303-310.

Visser M, Bouter LM, McQuillan GM, Wener MH, Harris TB. (1999). Elevated C-reactive protein level in overweight and obese adults. JAMA. 282, 2131-2135.

Wannamethee SG, Lowe GD, Whincup PH, Rumley A, Walker M, Lennon L. (2002). Physical activity and hemostatic and inflammatory variables in elderly men Circulation, 105, 1785-1790.

Wannamethee SG, Shaper AG, Walker M. (1998). Changes in physical activity, mortality and incidence of coronary heart disease in older men. Lancet, 351, 1603-1608

Weight LM, Alexander D, Jacobs P. (1991). Strenuous exercise analogous to the acute-phase response? Clin Sci (Lon), 81, 677-683.

Wilmore, J.H., J.P. Despres, P R. Stanforth, et.al. (1999). Alteration in body weight and composition consequent to $20 \mathrm{wk}$ of endurance training: The HERITAGE family study. AM. J. Clin. Nutr, 70, 346-352.

Witztum JL, (1997). Immunological responses to oxidized LDL. Atherosclerosis, 131, 59-511.

WMADH. World Medical Association Declaration of Helsinki. (2000). The Journal of the American Medical Association, 20, 3043-3045.

You T, Berman DM, Ryan AS, Nicklas BJ. (2004). Effects of hypocaloric diet and exercise training on inflammation and adipocyte lipolysis in obese postmenopausal women. J Clin Endocrinol M, 89, 1739-1746.

Yudkin JS, Stehouwer CD, Emeis JJ, Coppack SW. (1999). C-reactive protein in healthy subjects: associations with obesity, insulin resistance, and endothelial dysfunction: a potential role for cytokines originating from adipose tissue? Arterioscler Thromb Vasc Biol, 19, 972-978.

Ziccardi P, Nappo F Giugliano G, Esposito K, Marfella R, Cioffi M, D'andrea F, Molinari AM, Giugliano D. (2002). Reduction of inflammatory cytokine concentrations and improvement of endothelial functioned in obese women after weight loss over one year. Diabetes, 51, 1596-1600. 